\title{
HEAVY METALS AND MACRONUTRIENTS CONCENTRATION IN OREOCHROMIS NILOTICUS AND TILAPIA ZILLII FISH SPECIES INHABITING SOME EGYPTIAN LAKES AND EL-SALAM CANAL
}

\author{
Amaal M. Abdel-Satar and Amal M. Yacoub \\ National Institute of Oceanography and Fisheries, Inland Water \\ Branch. Cairo. Egypt
}

Key words: heav'y metals. macronutrients, Oreochromis niloticus. Tilapia =illii. Lake Manzalah. Lake Qarun. El-Salam Canal

\section{ABSTRACT}

The present study was initiated to assess the levels of Fe, Mn, $\mathrm{Zn}$. $1 \mathrm{Cu} . \mathrm{Ni}$. Co. $\mathrm{Pb}$ and $\mathrm{Cd}$ together with $\mathrm{Na}, \mathrm{K}, \mathrm{Ca}$ and $\mathrm{Mg}$ in liver and muscle of Tilapia =illii from three different aquatic ecosystems namely. Lake Manzaiah (Brackish water). Lake Qarun (Saline water) and El-Salam Canal (fresh water) and Oreochiomis niloticus from Lake Manzalah and El-Salam Canal throughout four seasons (19992non). The present results revealed that liver has higher tendency to accunulate $\mathrm{Fe}$ and $\mathrm{Cu}$ more than the other studied heavy metals for $O$. niloticus and $T$. zillii in different studied sites. $\mathrm{Zn}$ followed $\mathrm{Fe}$ in the accumulation abundance in muscle tissues of the two studied species and Cd was the lowest one. The fluctuation of metal concentrations in muscle tissues for $O$. niloticus and $T$. sillii exhibited the following descending order $\mathrm{Fe}>\mathrm{Zn}>\mathrm{Mn}=\mathrm{Cu}=\mathrm{Ni}=\mathrm{Co}=\mathrm{Pb}>\mathrm{Cd}$. while the abundance order of the same metals in liver tissues was: $\mathrm{Fe}>\mathrm{Cu}>\mathrm{Zn}>\mathrm{Mn}>\mathrm{Ni}>\mathrm{Co}=\mathrm{Pb}>\mathrm{Cd}$.

\section{INTRODUCTION}

In aquatic ecosystems. fish integrate and reflect the effects of numerous interacting biotic and abjotic factors (Eastwood and Couture. 2002). Although anthropogenic stresses such as metal contaminants adversely affect fish. these organisms are typically subjected to numerous stressors including unfarorable or fluctuating temperature. low dissolved oxygen. elevated sediment metal load. high water velocity. limited food availability and other types of episodic variables. All these factors. individually or together. can impose considerable stress on physicological systems of fish and impair their health or condition (Wedemeyer al al. 1996 ). 
Fish are able to uptake and retain heavy metals dissolved in water via active or passive processes (Ay et al. 1999). Toxic effects of metals occur after excretory. metabolic. storage and detoxification mechanisms are no longer able to match with uptake rates (Longston. 1990; Roesijadi and Robinson. 1994).

All heavy metals are potentially harmful to most organisms at some levels of exposure and absorption. Their presence in the environment has increased in some areas to levels which threaten the health of aquatic and terrestrial organisms. man included (Saeed. 1998). Stewart (1999) reported that metal toxicity in nature is determined to a great extent by the availability of individual metals for uptake by organisms.

The passage of different environmental pollutants to their aquatic systems demonstrates the need for a comprehensive study for their effects on living resources. Waste discharge never occurs singly but always as a mixture. Meanwhile, the resistance and sensitivity of organisms to pollutants are highly specific (Jana and Choudhuri. 1994).

Abdel-Satar and Shehata. (2000) concluded that the fish flesh $O$. niloticus and $T$. zillii is contaminated with both lead and cadmium for fish caught from sites more close to the sources of industrial. agricultural and domestic effluents in the River Nile and they added that the flesh of $T$. zillii has high affinity for its metal uptake than that for $O$. niloticus.

Lake Manzalah was subjected to excessive and progiessive organic and inorganic pollution from different sources. The lake has - become a sick pond after these serious changeable conditions of its environment. Ibrahim et al. (1999) stated that the fish in Lake Manzalah is characterized by slow growth rates, where the small illegal-sized caught fish contribute a remarkable portion (63-96\%) of the lake fishery. This was attributed to eutrophication and pollution (Abdel-Baky \& Bahnasawy, 1994 \& El-Caryoni, 1994). Mohamed et al. (1999) stated that bioaccumulation of heavy metals in fish may critically influence the growth rate and the quality of fish. The southern sector of Lake Manzalah receives $75 \%$ of the total annual drainage water to the lake from Hadous, Ramsis and Bahr El-Bagar drains. These drains play an important role in increasing the eutrophication condition of the lake water (Abdel-Satar, 2001). 
El-Salam Canal is carrying the Nile waters from Damietta branch upstream to Faraskour Barrage. The canal receives increasing amount of agricultural drainage water, which may exert considerable changes in the physical. chemical and biological properties. Sabae and Abdel-Satar (2001) suggested that the gradual increase in chemical character from up- to down strean and the irregular seasonal changes in the metal contents of the canal water might be related to the agricultural wastes discharged into the canal.

Lake Qarun receives the agricultural drainage water from surrounding cultivated lands. Most of the drainage water reaches the lake by two greatest drains, El-Batts (at the northeastern corner) and El-Wadi drains (near mid point of the southern shore). Ali (2002) determined some trace elements ( $\mathrm{Zn} . \mathrm{Cr}, \mathrm{Co}, \mathrm{Ni}, \mathrm{Pb}, \mathrm{Cd}$ and $\mathrm{As}$ ) in different organs (liver. Kidney and muscle) in $T$. zillii and Solea vulgiris caught from Lake Qarun and reported that Solea vilgaris showed more accumulative tendencies than $T$. sillii. Also, the kidney showed more accumulation of the studied elements followed by liver and muscle.

The aim of this study is to compare between the concentrations of some heavy metals and macronutrients in the muscle and liver of the most common and commercial fish species. namely $O$. niloticus and $T$. zillii inhabiting three different aquatic ecosystems in Egypt.

\section{MATERIALS AND METHODS}

Fish specimens of $O$. niloticus and $T$. zillii were caught seasonally from three sites along the southern sector of Lake Manzalah (sites 1, 2 and 3) and two sites from El-Salam canal up to $63 \mathrm{Km}$ ( sites 4 and 5) during the period from autumn 1999 to summer 2000. In addition to one site in Lake Qarun in the eastern region (infront of El-Batts drain) were chosen for $T$. zillii during the same period (site 6) (Fig. 1).

Samples penaining to $O$. niloticus and $T$. zillii were obtained in a controlled weight range of $100-150 \mathrm{gm}$ for $O$. niloticus and $30-50$ gm for $T$. zillii from each site. After the dissection of fish samples. parts of liver and muscle individually of six specimens were mixed together. These composite samples were dried in an oven at $105^{\circ} \mathrm{C}$ for 24 hour to constant weight. Fish samples of one gm (muscle) and $0.5 \mathrm{gnn}$. (liver) dry weight were digested with $5 \mathrm{ml}$ conc. $\mathrm{HNO}_{3}$ and $5 \mathrm{mi}$ conc. perchloric acids and finally. the samples were filtered (Ghazaly: 1992). 
The metals (Fe. Mn. Zn. Cu. Pb. Cd. $\mathrm{Ni}$ and $\mathrm{Co}$ ) concentrations were determined using atomic absorption spectrophotometer (Hitachi model 170-30) with Graphite Atomizer (GA-2) and comparing the readings with a standard curve. For macronutrients (Na. K. Ca and $\mathrm{Mg}$ ). the samples were determined using atomic absorption spectrophotometer (Hitachi model 170-30).

\section{a. Heavy metals}

\section{RESULTS AND DISCUSSION}

The present investigation revealed that. bioaccumulation of the studied heavy metals in studied organs of fish species depends mainly on sampling sites. Moreover. seasonal variations showed higher residual values in hot than in cold seasons. The heavy metals concentrations of the studied species in different water bodies were presented in Tables (1-8).

The results indicated that. the iron concentrations in the $O$. nilolicus were ranging between $0.036-0.064$ and $0.301-0.710 \mathrm{mg} / \mathrm{g}$ dry wt. for muscle and liver. respectively, while the values for $T$. zillii were $0.034-0.132$ and $0.315-0.905 \mathrm{mg} / \mathrm{g}$ dry wt. The accumulation rates of $\mathrm{Fe}$ in $O$. niloticus and $T$. zillii were higher in liver than muscle. Mohamed et al. (1999) reported that the liver is the first sensitive organ for metal accumulation. On the other hand. muscle included the lowest levels of the heavy metals concentration.

For $T$, zillii the muscle showed high values of iron for fish caught from Lake Qarun (site 6) than the sites in Lake Manzalah and El-Salam Canal during different seasons except summer. while the fish caught from Lake Qarun had the minimum rate of accumulation in liver for $\mathrm{Fe}$ and $\mathrm{Mn}$ metals during all seasons. This may be attributed to the difference in type and amount of wastes discharged to the water bodies. Carbonell et al. (1998) reported that any increase in total dissolved metal concentration would correspondingly increase the free metal ions concentration, and thereby lead to an increase in metal uptake rate. If the rate of excretion does not follow a parallel increase, a net accumulation of metal occurs within the body. Fe was found to be the most abundant metal present in the fish tissue and liver for the two studied species.

Manganese levels were in the range of 1.904-7.010 and 2.301$5.511 \mu \mathrm{g} / \mathrm{g}$ for muscle of $O$. niloticus and $T$. zillii, respectively and for liver the ranges were $15.28-50.40$ and $15.66-51.45 \mu \mathrm{g} / \mathrm{g}$. There is an increase in the concentrations of $\mathrm{Mn}$ during summer in fishes of most sites. In this concern, Phillips (1980) reported that many factors 


\section{HEAVY METALS AND MACRONUTRIENTS IN

affect the rate of accumulation of which seasonal variation in temperature was taken into consideration. Gomaa (1995) added that weakly bound metals in soft organ (liver) may be more easily influenced by seasonal changes than strongly bound metals in flesh

It is commonly accepted that zinc is an essential micronutrient required for normal grouth and metabolic functions by terrestrial vertebrates as well as various fish species (Gatlin et al., 1991 ; Lan er al., 1995). The findings of the present study show that for $T$. zillii. $\mathrm{Zn}$ accumulated more in the muscle of fish from site 6 (Lake Qarun) than the sites of Lake Manzalah and El-Salam Canal. On the contrary, the liver showed the minimum rate of accumulation of $\mathrm{Zn}$ in fish from Lake Qarun.

It is conspicuous that, $\mathrm{Zn}$ followed $\mathrm{Fe}$ in the accumulation abundance in fish tissue of the two species and $C d$ was the lowest one. Similar findings were reported by Jaffar et al. (1988): Schuhmacher et al. (1992); Abdel-Moneim et al. (1994 b): Zyadah (1997) and Abdel-Baky et al. (1998).

Copper is an essential trace elements in fish metabolism (Lan et al. 1995). However. it is different from $\mathrm{Zn}$ in that its presence in the aquatic environmental with relatively lower concentration is known to be harmful (Lan and Chen. 1991). Cu levels in the investigated fish muscle ranged between 2.07-8.28 and 2.07-7.66 $\mu \mathrm{g} / \mathrm{g}$ for $O$. niloticus and $T$. zillii. respectively. According to FAO. 1983. the studied fishes of different sites were not contaminated with $\mathrm{Zn}(40 \mu \mathrm{g} / \mathrm{g}$ dry wt.) and $\mathrm{Cu}(20-30 \mu \mathrm{g} / \mathrm{g} \mathrm{dry}$ wt.)

Bioaccumulation of heary metals does not only depend on the structure of the organ but also on the interaction between metals and the target organs (Sorensen 1991: Mohamed at al., 1999). For $O$. niloticus and $T$. zillii, the present results showed that liver has higher tendency to accumulate $\mathrm{Fe}$ and $\mathrm{Cu}$ than the other studied heavy metals in different sits. These results agree with those reported by Abdel-Baky and Zyadah (1998) for Lake Manzalah.

Contrary to $\mathrm{Zn}$. Cu showed high rate of accumulation in liver for T. zillii fishes from Lake Qarun than the other water bodies during different seasons except summer. The liver of the two species showed high values during hot seasons for all studied sites. This may be attributed to the increase of load in drainage water comtaining high amount of $\mathrm{Cu}$. Our data support the conclusion of Taylor ef al. (2000) that in fish tissue. Cu concentrations rise only after exposure to high levels of $\mathrm{Cu}$ sources. 
The present results revealed that the accumulation pattern of lead in muscle (2.00-5.80 and 2.03-8.79 $\mu \mathrm{g} / \mathrm{g}$ for $O$. niloticus and $T$. zillii. respectively) was lower than the values in liver (4.09-17.09 and 4.20-19.06 $\mu \mathrm{g} / \mathrm{g}$ ). El-Nabawi et al. (1987) stated that lead resides in muscle tissue are usually lower than these in other organs. Barak and Mason (1990) recorded that lead levels were several times higher in liver than flesh. Muscle of $T$. zillii in Lake Qarun (site 6) showed accumulation levels higher than that recorded in Lake Manzalah and El-Salam Canal sites during different seasons. On the contrary. the liver levels for Lake Manzalah and El-Salam Canal sites showed higher accumulation than Lake Qarun during hot seasons.

Cadmium is a non-essential element that has severe toxic effects on aquatic organisms (Sorensen. 1991; Hollis et al.. 1999). In fish. Cd can damage gills (Voyer et al., 1975) result in skeletal deformities and disturb calcium balance (Wicklund-Glynn et al.. 1994). The levels of $C d$ in muscle were found to be $0.438-1.214$ and $0.464-1.628 \mu \mathrm{g} / \mathrm{g}$ for $O$. niloticus and $T$. zillii, respectively.

The fish of studied. water bodies are considered heavily contaminated with $\mathrm{Cd}$ and $\mathrm{Pb}$ where their levels were more than the permissible limits of FAO. $1983(0.5 \mu \mathrm{g} / \mathrm{g}$ dry wt. for $\mathrm{Cd}$ and $\mathrm{Pb})$ and Australian NH\&MRC, $1987(0.2 \mu \mathrm{g} / \mathrm{g}$ dry wit. for Cd and 1.5 $\mu \mathrm{g} / \mathrm{g}$ dry wt. for $\mathrm{Pb}$ ). In general, the highest $\mathrm{Cd}$ concentrations were found in the liver $(0.757-2.877$ and $0.874-3.440 \mu \mathrm{g} / \mathrm{g}$ in $O$. niloticus and T. zillii, respectively). The enrichment of heavy metals in liver was reported in the studied sites. Ibrahim et al. (1999) stated that the high metal content in the liver may be attributed to its multifunctional role in detoxification and storage processes. For $T$. zillii, Lake Qarun showed the highest values of $\mathrm{Cd}$ in muscle and liver during different seasons except autumn for muscle at site 1 $(1.513 \mu \mathrm{g} / \mathrm{g})$. This is confirmed with that reported by Koli et al.(1978), who stated that salt water fish have more heavy metals concentrations ( $\mathrm{Fe}, \mathrm{Zn}, \mathrm{Mn}, \mathrm{Cu}$ and $\mathrm{Cd}$ ) than the fresh water fish.

Nickel levels ranged between 2.063-7.020 and 2.376-5.940 $\mu \mathrm{g} / \mathrm{g}$ for muscle of $O$. niloticus and $T$. zillii, respectively. Several variations in liver $\mathrm{Ni}$ concentration were observed in the most studied sites (5.436-28.910 and 5.874-41.440 $\mu \mathrm{g} / \mathrm{g}$ ), with higher levels in the hot seasons.

During cold seasons, El-Salam Canal sites showed high accumulation of $\mathrm{Ni}$ level in liver of $O$. niloticus and $T$. zillii, while Lake Manzalah sites showed higher level during hot seasons for the two species. The dissimilarities in these results may be attributed 


\section{HEAVY METALS AND MACRONUTRIENTS IN

substantially to the changeable ecological conditions in the studied aquatic systems as a result of fluctuation in the amounts of agricultural drainage water, sewage effluents and industrial wastes. The accumulation of trace metals depends on the nature and the function of the tissue and ability of fish in regulating the level of the metals in their bodies during the uptake and elimination processes (Faris et al., 1998).

The bioaccumulation rate of cobalt recorded the highest values in liver (4.19-19.69 and 4.31-19.39 $\mu \mathrm{g} / \mathrm{g}$ for $O$. niloticus and $T$. zillii. respectively) than in muscle (2.50-6.10 and $2.70-5.23 \mu \mathrm{g} / \mathrm{g})$ during different seasons. In cold seasons, the arrangement of the studied aquatic systems according to the ability of their liver tissue to accumulate Co metal was as follow: Lake Qarun> Lake Manzalah = El-Salam Canal, while the reverse w'as observed during hot seasons.

Ali (2002) studied the accumulated concentrations of $\mathrm{Ni}$ and Co in $T$. zillii collected from Lake Qarun. He found the nickel range was 5.0-6.7 and 6.7-11.0 $\mathrm{gg} / \mathrm{g}$ in flesh and liver, respectively. while the Co range was $3.9-5.0$ and $7.6-10.3 \mu \mathrm{g} / \mathrm{g}$. These results agree with the present findings but with slight increase in Ni muscle level.

The obtained results showed that the fluctuation of metal concentration in muscle tissues for $O$. niloticus and $T$. zillii exhibited the following descending order. $\mathrm{Fe}>\mathrm{Zn}>\mathrm{Mn}=\mathrm{Cu}=\mathrm{Ni}=\mathrm{Co}=\mathrm{Pb}>\mathrm{Cd}$. while the abundance order of metal concentration in liver tissue was $\mathrm{Fe}>\mathrm{Cu}>\mathrm{Zn}>\mathrm{Mn}>\mathrm{Ni}>\mathrm{Co}=\mathrm{Pb}>\mathrm{Cd}$.

It can be can concluded that the accumulation levels of heary metals in the studied organs of fish reflect to high extent the degree of aquatic environmental pollution by such metals. Therefore. fisin can be considered as a valid indicator for pollution of the aquatic environment (Shakweer. 1998)

Also. the study gives a declaration of the elevated levels metal pollution in the different studied areas due to continuously discharging of industrial. agricultural and domestic effluents. Therefore. strict environmental regulations will require the development of hetter indicators of metal effects on aquatic ecosı̀stems including fish.

\section{b. Macronutrịents:}

Concentration distribution of macronutrients in the studied fish species during different seasons are collected in Tables (9-12). 
It is clear from the present results that the accumulation pattern of $\mathrm{Na}$ showed a similar trend in both fish species with a noticeable increase in the liver $(3.01+-7.96 \mathrm{mg} / \mathrm{g})$ than the muscle $(2.341-3.73$ $\mathrm{mg} / \mathrm{g}$ ). These results can be explained on the basis of tendency of soft tissues to accumulate the metals than hard ones (Abdel-Moneim el al. 1994 a).

The accumulation pattern of macronutrients showed slight increase in the muscle of $T$. Zillii during most seasons for the fish collected from Lake Qarun. Also. Ca and Mg liver content showed the same phenomena in Lake Qarun. Meanwhile, high levels of liver $\mathrm{Na}$ and $\mathrm{K}$ were recorded in Lake Manzalah and El-Salam Canal fishes. However. several instances of individual variability could be observed in the macronutrient data with respect to various fish from different sites.

The obtained results showed that, the fluctuation of macronutrients concentrations in fish organs (muscle and liver) exhibited the following descending order $\mathrm{Na}=\mathrm{K}>\mathrm{Ca}>\mathrm{Mg}$.

\section{REFERENCES}

Abdel-Baky, T.E. and Bahnasawy. M.H. (1994). Age and growth of grey mullet. Liza ramada Risso, (Mugil capilo cur.) in Lake Manzalah. Egypt, J. Egypt. Ger. Soc. Zool., /3(B): 169-189.

Abdel-Baky, T.E. and Zyadah. M.A. (1998). Effect of accumulation of copper. cadmium and zinc on some biciogical parameters of some marine fishs from the northern region of Lake Manzalah, Egypt. J. Egypt Ger. Soc. Zool.: 27(B): $1-19$.

Abdel-Baky, T.E.; Hagras. A.E.; Hassan, S.H. and Zyadah. M.A. (1998). Heavy metals concentration in some organs of Oreochromis (Tilapia) aureus stein in Lake Manzalah. Egypt. J. Egypt Ger. Soc. Zool., 25(A): 237-256.

Abdel-Moneim, M.A.; Aly, A. and El-Moselhy (1994 a). Levels of $\mathrm{Cd}, \mathrm{Pb}, \mathrm{Cu}$ and $\mathrm{Zn}$ in Mugil seheli from Suez Bay: "Northem part of the Gulf of Suez, Egypt", Bull. Nat. Inst. Oceanogr. \& Fish., 20(1): 69-82.

Abdel-Moneim, M.A.; El-Deek, M.S.; Beltagi, A.I.; Naguib, M.M. and Naguib, K. (19.94 b). Distribution of heavy metals in some species of edible fish from the Red Sea, Bull. Of H.I.P.H., (t): 957-972. 


\section{HE A VY METALS AND MACRONUTRIENTS IN 105 OREOCHROMIS NILOTICUS AND TILAPIA ZILLII}

Abdel-Satar, A.M. (2001). Environmental studies on the impact of the drains effluent upon the southern sector of Lake Manzalah. Egypt. Egypt. J. Aquat. Biol. \& Fish., 3: 17-30.

Abdel-Satar, A.M. and Shehata, M.B. (2000). Heavy metals accumulation and macronutrient contents in the flesh of two edible fish inhabiting the River Nile. Egypt, J. Egypt. Acad. Soc. Environ. Develop.. 1(1): 99-117.

Ali. M.H.H. (2002). Impact of agricultural and sewage effluents on the ecosystem of Lake Qarun. Egypt, Ph.D. Thesis, Fac. of Sci., Al-Azhar Univ.

Australian NH\&MRC, (1987). Food Standards code-1987. Australian Government Publishing Service. Canberra.

Ay. O.: Kalay, M.: Tamer. L. and Canli, M. (1999). Copper and lead accumulation in tissues of a freshwater fish Tilapia =illii and its effects on the branchial Na.K-ATPase activity. Bull. Environ. Contam. Toxicol. 62: 160-168.

Barak N.A.E. and Mason, C.F. (1990). Mercury, cadmium and lead concentrations in five species of freshwater fish from Eastern England, Sci. total Environ., 92: 257-263.

Carbonell, G.: Ramos. J. and Tarazona. J.V. (1998). Heavy metals in shrimp culture areas from the Gulf of Fonseca. Central America. II. Cultured shrimps, Bull. Environ. Contam. Toxicol. 60: 260-265.

Eastwood, S. and Couture. P. (2002). Seasonal varations in condition and liver metal concentrations of yellow perch (Perca flavescens) from a metal-contaminated environment. Aquat. Toxicol.. 58: 43-56.

El-Caryoni. E.A.(1994). Bio-economic study to fishery management in Lake Manzalah. Alex. J. Agric. Rec.. 39(2): 37-53.

El-Nabawi. A.: Heinzow: B. and Kruse. H. (1987). As. Cd. Cu. Pb. $\mathrm{Hg}$ and $\mathrm{Zn}$ in fish from Alexandria region. Egypt. Bull. Environ. Contam. Toxicol. 39: 889-897.

FAO. (1983). Compilation of legal limits for hazardous substances in fish and fishery products. FAO. Fishery circular no. pp. 464. 5-100.

Faris. J.M.: Al-Imarah: Al-Kafaji. B.Y.D. and Mohamed. A.R.M. (1998). Trace metals in waters. sediments and fishes from North West Arabian Gulf. Bull. Nat. Inst. Occanogr. \& Fish.. 24: $403-416$. 
Gatlin. D.M.ill: Connell. J.P. and Scarpa. J. (1991). Dietary zinc requirement of the red drum Sciaenop ocellaths. Aquacul.. 02: 259-265.

Ghazaly. K.S. (1992). A comparative study of trace elements Accumulation in tissues of the releost Tilapia =illii from contaminated and clean areas. Bull. Nat. Inst. Dceanogr. \& Fish.. 18: $37+11$.

Gomaa. M.N.E. (1995). Recycling study of some heary metals in the Egyptian aluatic ecosystem. Food Chem.. 54: 297-303.

Hollis, L.: McGeer. J.C.: McDonald, D.G. and.Wood. C.M. (1999). Cadmium accumulation. gill $\mathrm{Cd}$ binding. acclimation and physiological effects during long term sublethal $\mathrm{Cd}$ exposure in rainbow trout. Aquatic Toxicol. f6: 101-119.

Ibrahim. A.M; Bahnasawy, M.H.; Mancy, S.E. and El-Fayomy. R.I. (1999). Heavy metal accumulation in water. sediment and some fishes in Lake Manzalah. Egypt. J. Egypt Ger. Soc. Zool., 29(B): 43-58.

Jaffar. M.; Ashraf, M. and Rasod, A. (1988). Heavy metal contents in some selected local fresh water fish and relevant water. Pak. J. Sci. Ind. Res., 31(3): 189-193.

Jana. S. and Choudhuri, M.A. (1994). Synergistic effects of heavy metal pollutants on senescence in submerged aquatic plants. Wat., Air \& Soil Pollution, 21: 351-357.

Koli. A.K.; Sandhu. S.S.; Canty, W.T.; Felix, K.L.; Reed, R.J. and Witmore, R. (1978). Trace metals in some fish species of South Carolina, Bull. Environ. Contam. Toxicol. 20: 328-331.

Lan, W.G.; Wonm, M.K.; Chen. N. and Sin, Y.M. (1995). Effect of combined copper, 'zinc, chromium and selenium by orthogonal array design on alkaline phosphatase activity in liver of the red sea bream, Chrysophrys major, Aquacul.. 131: 219-230.

Lan. W.G.and Chen, N. (1991). Acute toxicity of $\mathrm{Hg}, \mathrm{Cu}, \mathrm{Cd}, \mathrm{Zn}$ to larvae of red sea bream, Chrysophrys major, Mar. Sci., 5: 56-59.

Longston, W.J. (1990): Toxic effects of metals and the incidence of marine ecosystems In heavy metals in the marine environment (eds. Fumess R.W., Rainbow, P.S.), CRC Press, New York,.256 pp.

Mohamed, H.A.; Marie, M.A.S. and Zaghloul, K.H. (1999). Seasonal effects of the industrial effluents on the Nile catfish; 
HEAVY METALS AND MACRONLTRIENTS IN 107 OREOCHROMIS WILOTICLS AND TILAPIA ZILLII

Clarias gariepinus, J. Egypt. Ger. Soc. Zool. 2s(A): $365-391$.

Phillips. D.J.H. (1980). Quantitative Aquatic Biological Indicators. Applied Science Publishers. London. U. K.

Roesijadi G. and Robinson. W.E. (1994): Metal regulation in aquatic animals: Mechanisms of uptake. accumulation and release. In: Aquatic Toxicology: Nolcular biochemical and collutar perspectives (ed. Malins D.C.: Ostrander G.K.). Lewis Publishers, London. $539 \mathrm{pp}$.

Sabae. S.Z. and Abdel-Satar. A.M. (2001): Chemical and Bacteriological studies on El-Salam Canal. Egypt. J. Egypt. Acad. Soc. Environ. Develop., 2(1): 173-197.

Saeed. R.M.A.. (1998). A restoration toward toxic impact and bioaccumulation of zinc. cadmium and copper in the Nils tilapia Oreochromis niloticus, J. Egypt. Ger. Soc. Zool.. 25(A): 383-398.

Schuhmacher, M. Bosque, M.A.; Domingo. J.L. and Corbella. J. (1992). Heavy metals in marine species from the Tarragona Coast. Spain. J. Environ. Sci. Health. 27(7): 1939-1948.

Shakweer. L.M. (1998). Concentration levels of some trace metals in Oreochromis niloticus at highly and less polluted areas of Mariut Lake. J. Egypt Ger. Soc. Zool.. 25(A): 125-144.

Sorensen. E.M. (1991). Metal poisoning in fish. Ch. VI. Cadmium. CRC Press Boca Raton. F.L. pp. 175-234.

Stewart, A.R. (1999). Accumulation of Cd by a freshwater mussel (Pyganodon grandis) is reduced in the presence of $\mathrm{Cu}, \mathrm{Zn}$. $\mathrm{Pb}$ and Ni, Can. J. Fish. Aquat. Sci., 56: 467-478.

Taylor, L.N; McGeer, J.C.; Wood, C.M and McDonald. D.G. (2000). Physiological effects of chronic cooper exposure to rainbow trout (Oncorhynchus mykiss) in hard and soft water: evaluation of chronic indicators, Environ. Toxicol. Chem.. 19(9): 2298-2308.

Voyer, R.A.; Yevich, P.P. and Barszcz. C.A. (1975). Histological and toxicological resposes of the mummichog. Fundulus herteroclitus (L.) to combination of levels of cadmium and dissolved oxygen in a freshwater, Wat. Res., 9: 1069-1074. 
Wedemeyer, G.; Barton. B. and Mcleay. D. (1990). Stress and acclimation. In: Schreek. C.B.. Moyle, P.B. (eds.). Methods for fish biology. American fisheries society. Bethesda. MD. pp. 451-489.

V'icklund-Glynn, A.; Norrgren. L. and Mussener. A. (1994). Differences in uptake of inorganic mercury and cadmium in the gills of the zebrafish. Brachydanio rerrio. Aquat. Toxicol., 30: 13-26.

Zyadah. M. (1997). A study on the level of some heavy metals in River Nile estuary-Damietta Branch, Egypt, J. Egypt Ger. Soc. Zool., 23(A): 149-160. 


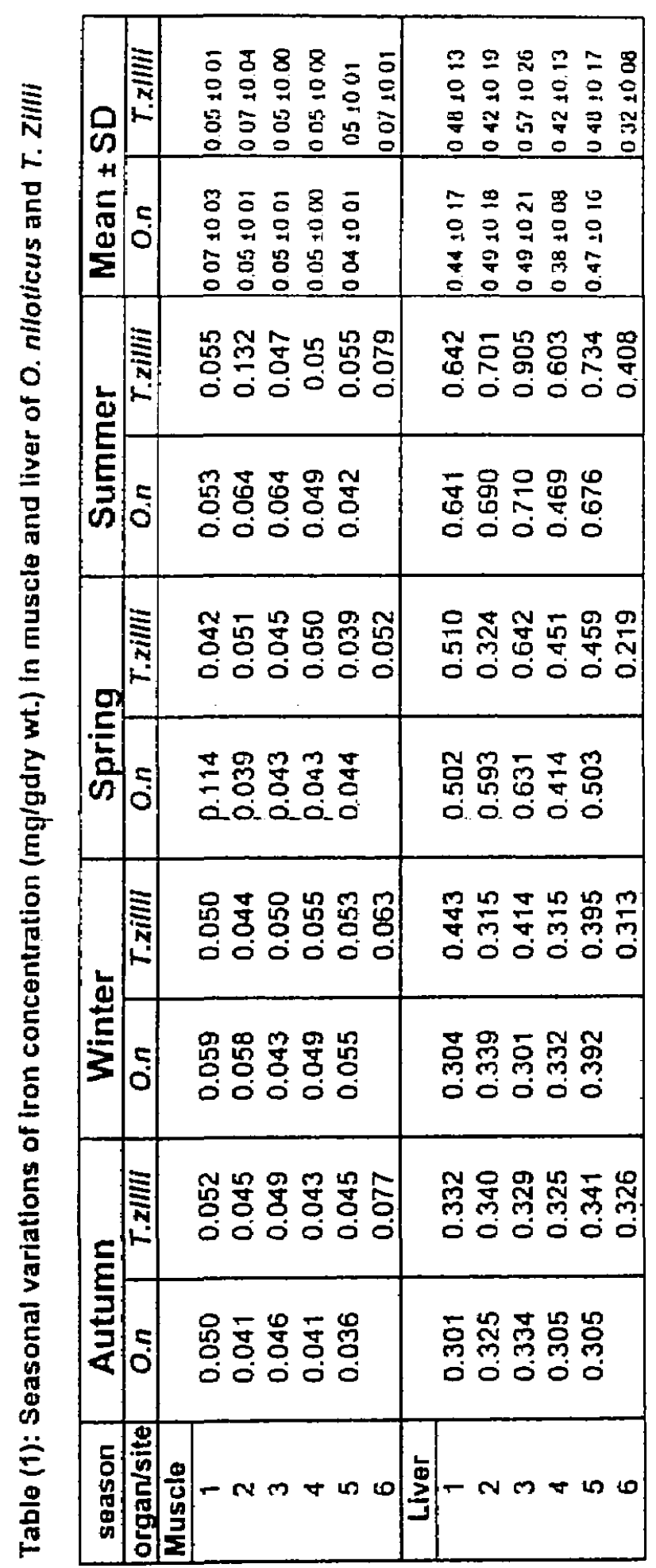

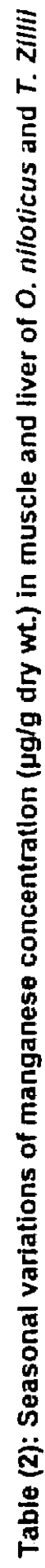

\begin{tabular}{|c|c|c|c|}
\hline$\stackrel{0}{\infty}$ & 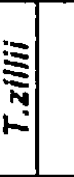 & 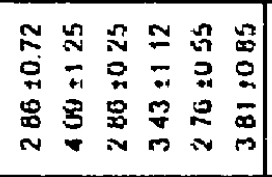 & 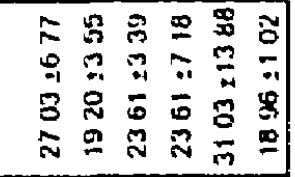 \\
\hline $\begin{array}{l}+1 \\
\frac{1}{0} \\
\frac{d}{2}\end{array}$ & 5 & 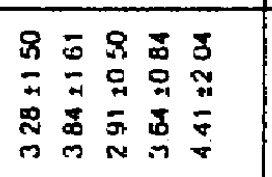 & 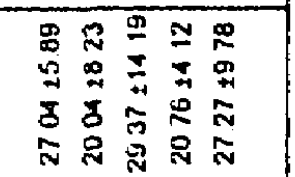 \\
\hline \multirow{2}{*}{ 总 } & ミָ & 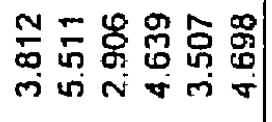 & 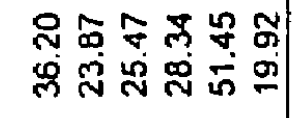 \\
\hline & & 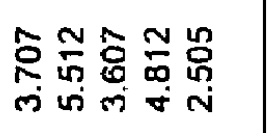 & 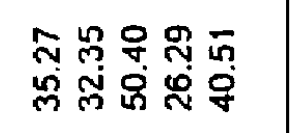 \\
\hline \multirow{2}{*}{ 일 } & : & 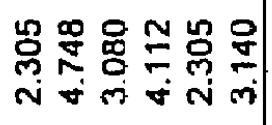 & 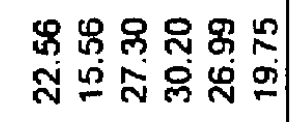 \\
\hline & & 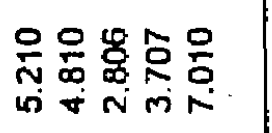 & 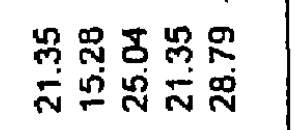 \\
\hline \multirow{2}{*}{$\frac{2}{3}$} & †. & 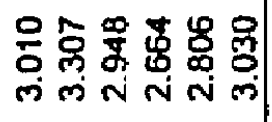 & 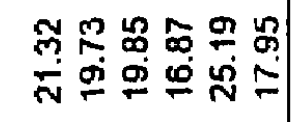 \\
\hline & 5 & 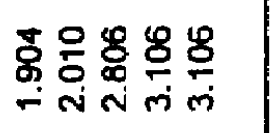 & 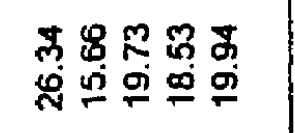 \\
\hline \multirow{2}{*}{$\frac{5}{\frac{E}{2}}$} & 㐫 & 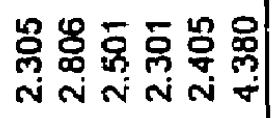 & 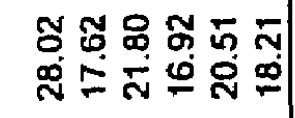 \\
\hline & & 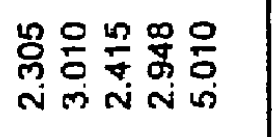 & 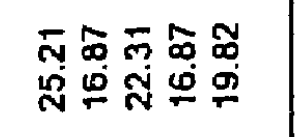 \\
\hline $\begin{array}{l}5 \\
0 \\
0 \\
8 \\
⿱ ⺊ 口 \\
n\end{array}$ & 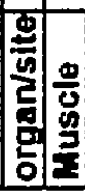 & $-n m \in \ln$ & ב \\
\hline
\end{tabular}




\begin{tabular}{|c|c|c|c|}
\hline or or $\Delta \omega N-\mid \frac{F}{\mathbb{m}}$ & OO OND & 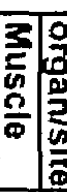 & $\mid \begin{array}{l}n \\
0 \\
0 \\
0 \\
0 \\
0 \\
0\end{array}$ \\
\hline 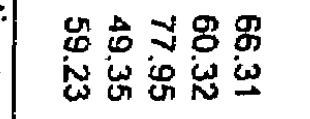 & 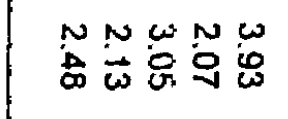 & & 2 \\
\hline 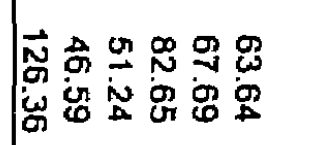 & 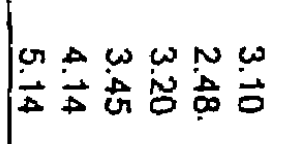 & & \\
\hline 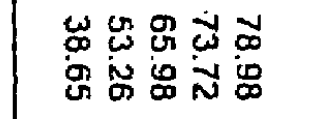 & 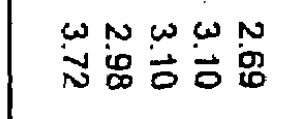 & & \\
\hline 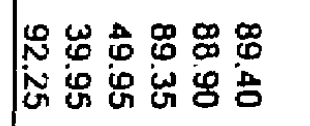 & 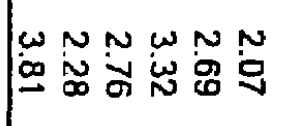 & & \\
\hline 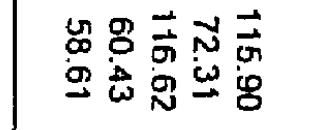 & & & 0 \\
\hline 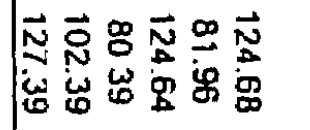 & 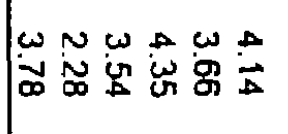 & 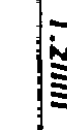 & \\
\hline 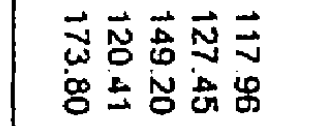 & 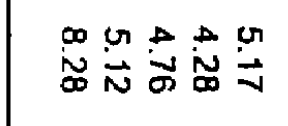 & & 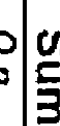 \\
\hline 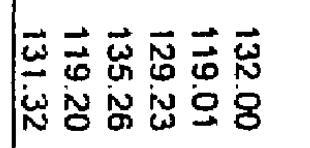 & 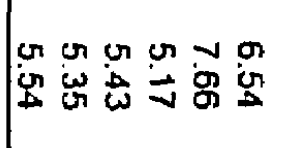 & 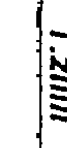 & $\sqrt{\pi}$ \\
\hline 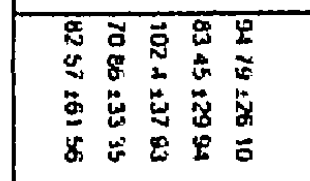 & 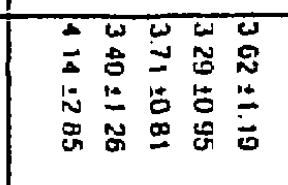 & & $\mid \begin{array}{l}3 \\
\frac{3}{2} \\
\frac{3}{2}\end{array}$ \\
\hline 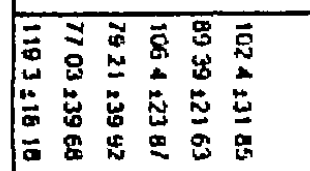 & 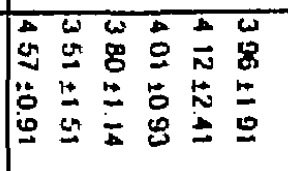 & 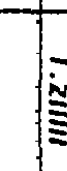 & 4 \\
\hline
\end{tabular}

\begin{tabular}{|c|c|c|c|}
\hline OC $\triangle$ O & on $\rightarrow \omega n-$ & 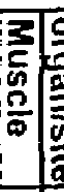 & 垈 \\
\hline 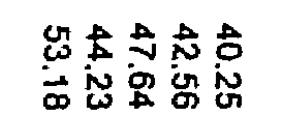 & 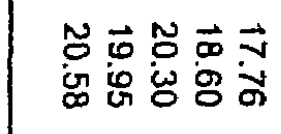 & & $\frac{2}{2}$ \\
\hline 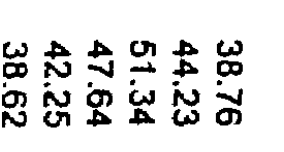 & 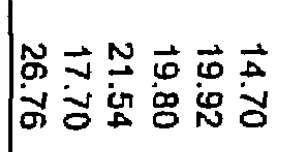 & & $\underline{-1}$ \\
\hline 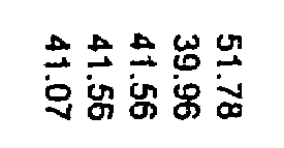 & 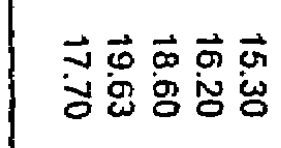 & & \\
\hline 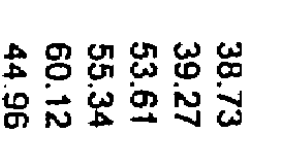 & 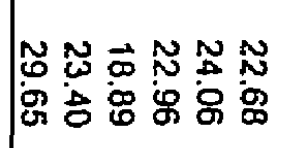 & & 年 \\
\hline 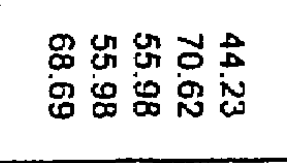 & 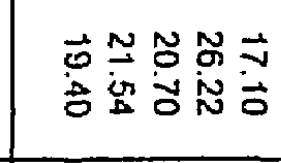 & & 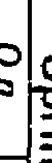 \\
\hline $\begin{array}{l}W \\
W \\
\infty\end{array}$ & 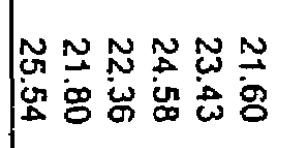 & & $\underline{z}$ \\
\hline 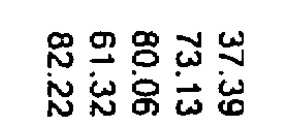 & 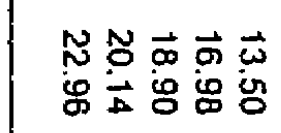 & & \\
\hline 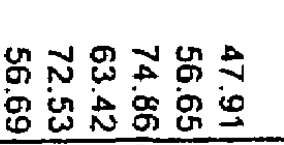 & 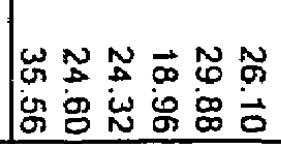 & & $\frac{G}{E}$ \\
\hline 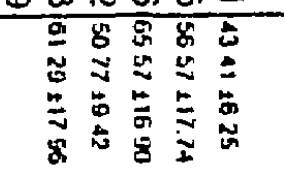 & 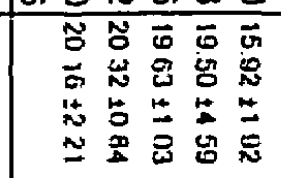 & & \\
\hline 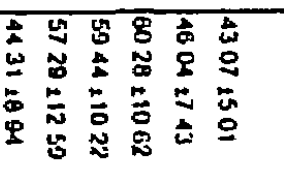 & 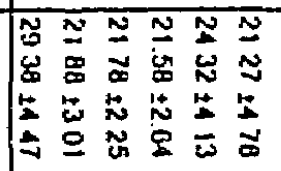 & & \pm 10 \\
\hline
\end{tabular}




\begin{tabular}{|c|c|c|c|}
\hline 只 & 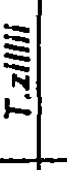 & 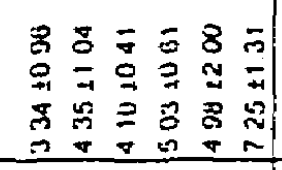 & 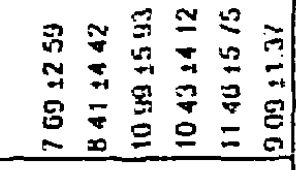 \\
\hline 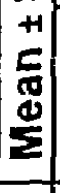 & & 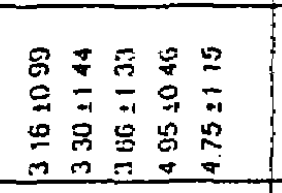 & 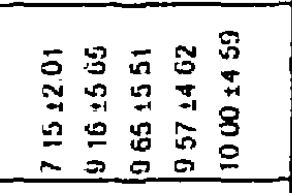 \\
\hline ఫ) & 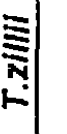 & 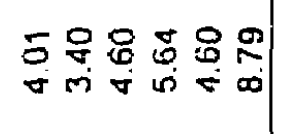 & 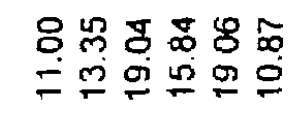 \\
\hline $\begin{array}{l}\bar{E} \\
\bar{N}\end{array}$ & & 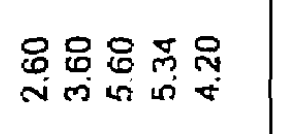 & 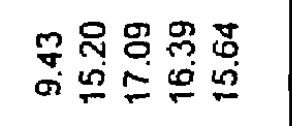 \\
\hline & 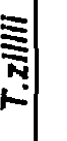 & 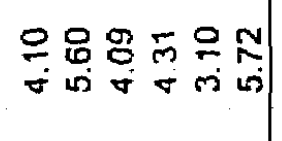 & $\begin{array}{l}\cong \infty \\
\infty \\
\infty\end{array}$ \\
\hline 임 & & 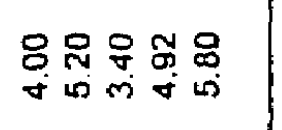 & 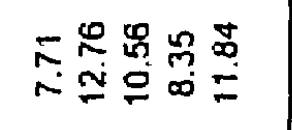 \\
\hline$\frac{1}{71}$ & 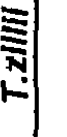 & 总品吕筞品令 & 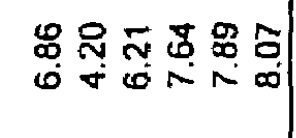 \\
\hline 5 & के & 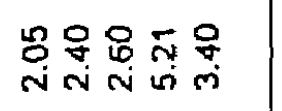 & 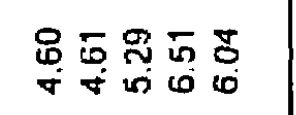 \\
\hline-1 & : & 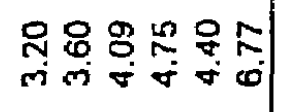 & 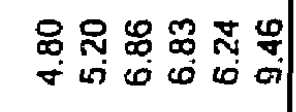 \\
\hline 至 & 5 & 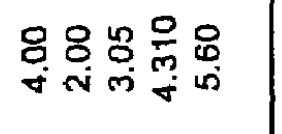 & $\begin{array}{l}98 \\
8 \\
0\end{array}$ \\
\hline 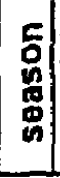 & 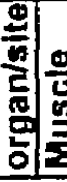 & $-\infty m$ & 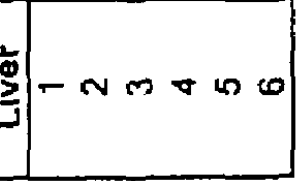 \\
\hline
\end{tabular}

\begin{tabular}{|c|c|c|c|}
\hline 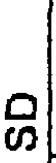 & 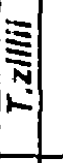 & 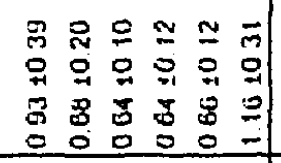 & 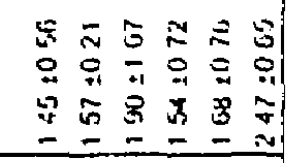 \\
\hline $\begin{array}{l}+1 \\
\frac{1}{2} \\
\mathbf{d} \\
\end{array}$ & 5 & 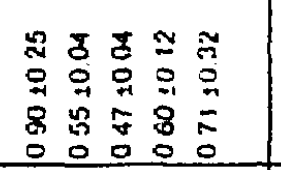 & 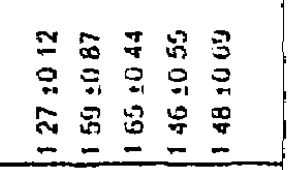 \\
\hline 包 & ָ- & 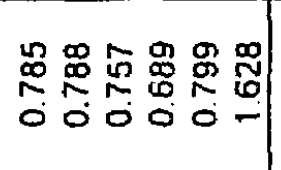 & 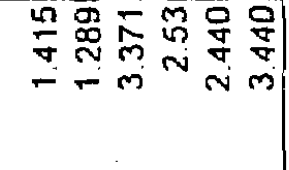 \\
\hline 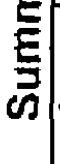 & 5 & 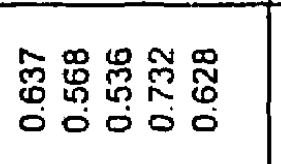 & 嵒号兽占思 \\
\hline 미 & 霛 & 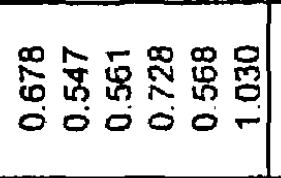 & 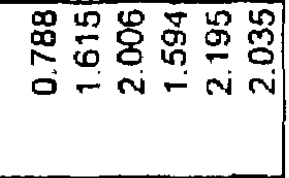 \\
\hline 동 & c. & 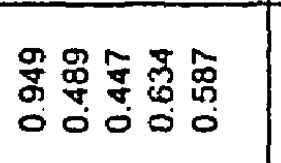 & 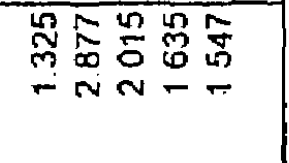 \\
\hline 与 & 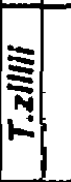 & 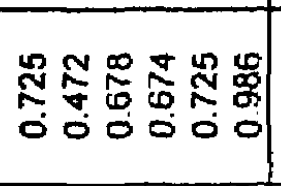 & 寽总总管总总 \\
\hline 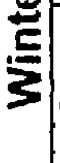 & : & 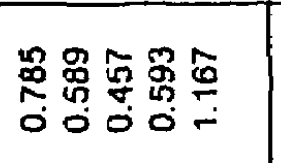 & 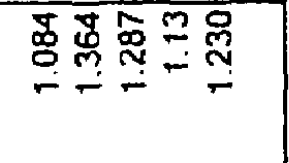 \\
\hline 드 & - & 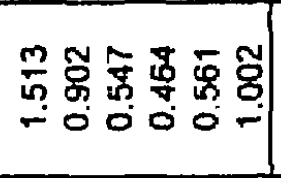 & 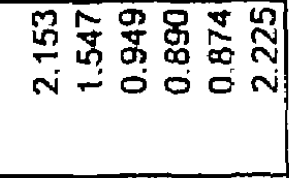 \\
\hline 晃 & ó & 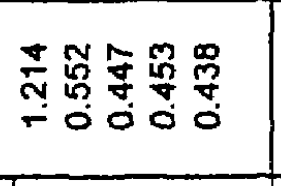 & 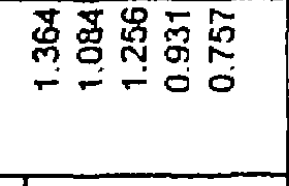 \\
\hline $\begin{array}{l}5 \\
0 \\
0 \\
0\end{array}$ & 兽 & $-N m$ & $-\alpha m \forall n \infty$ \\
\hline
\end{tabular}




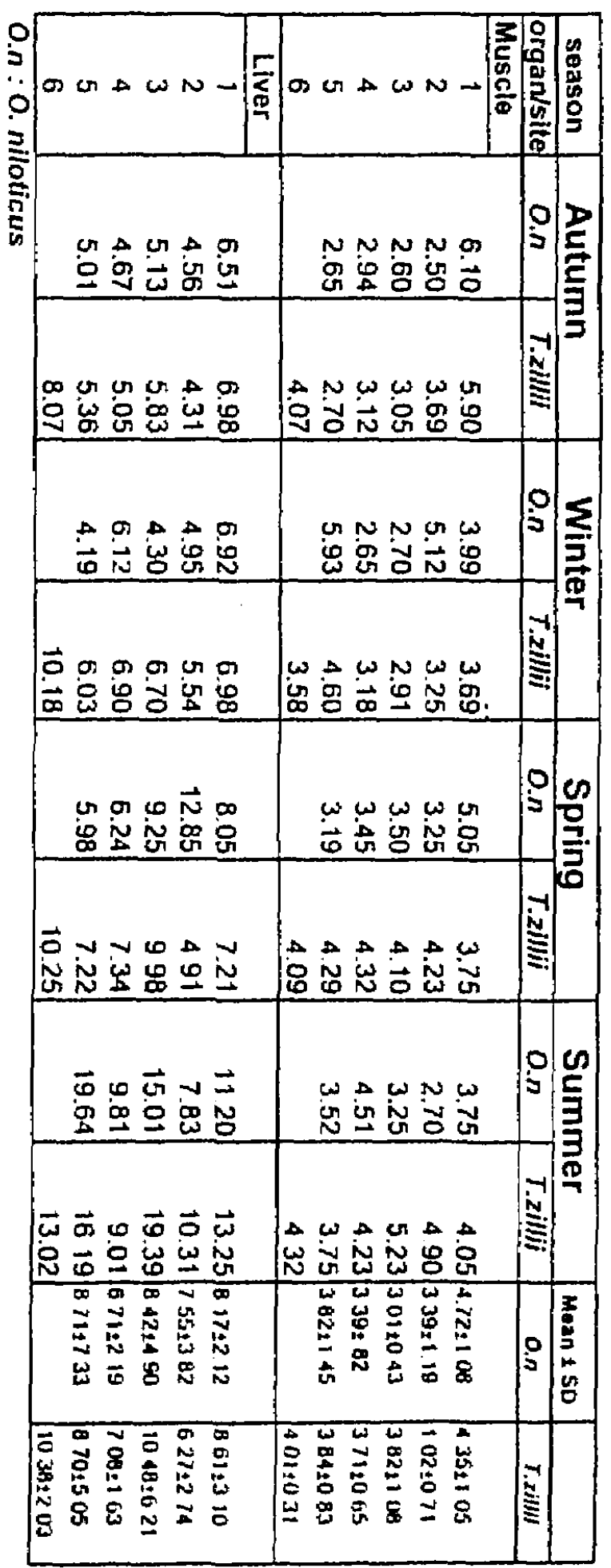

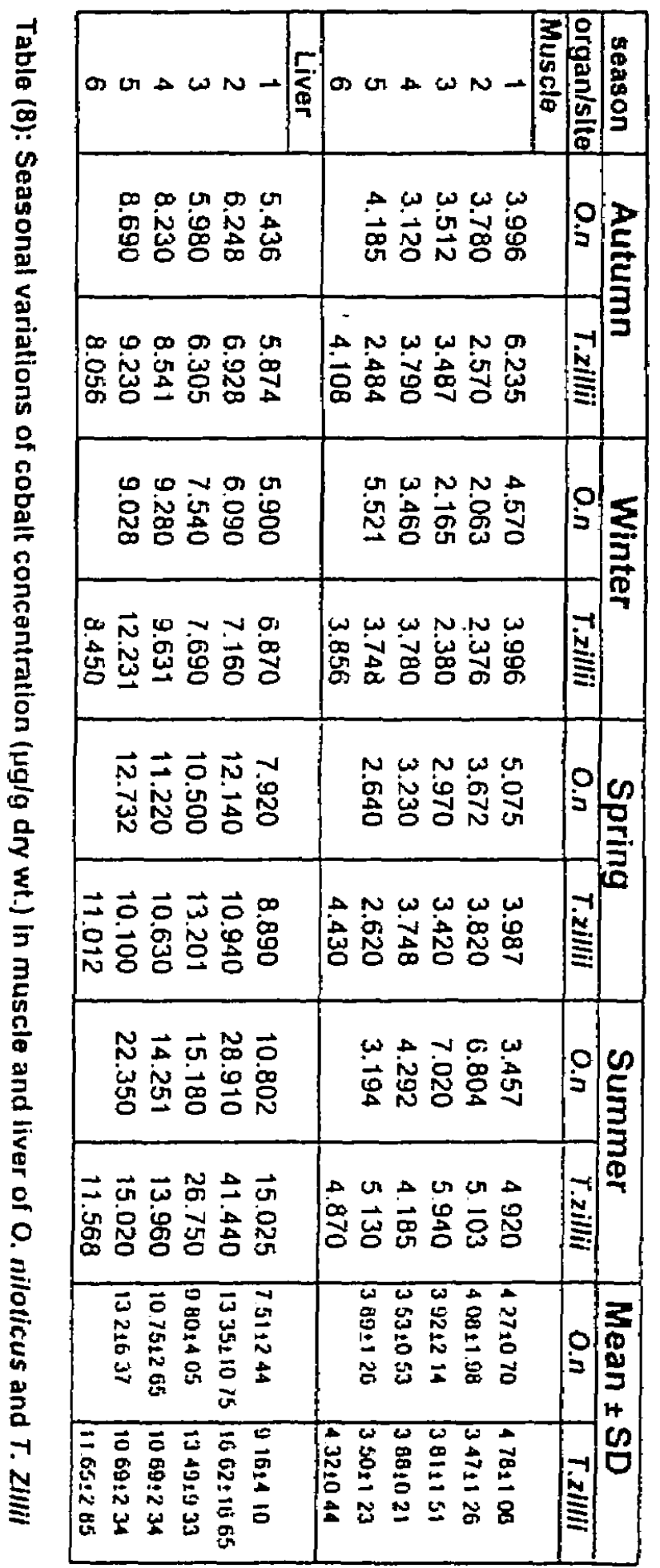

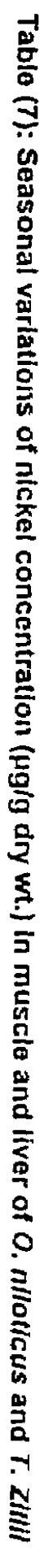




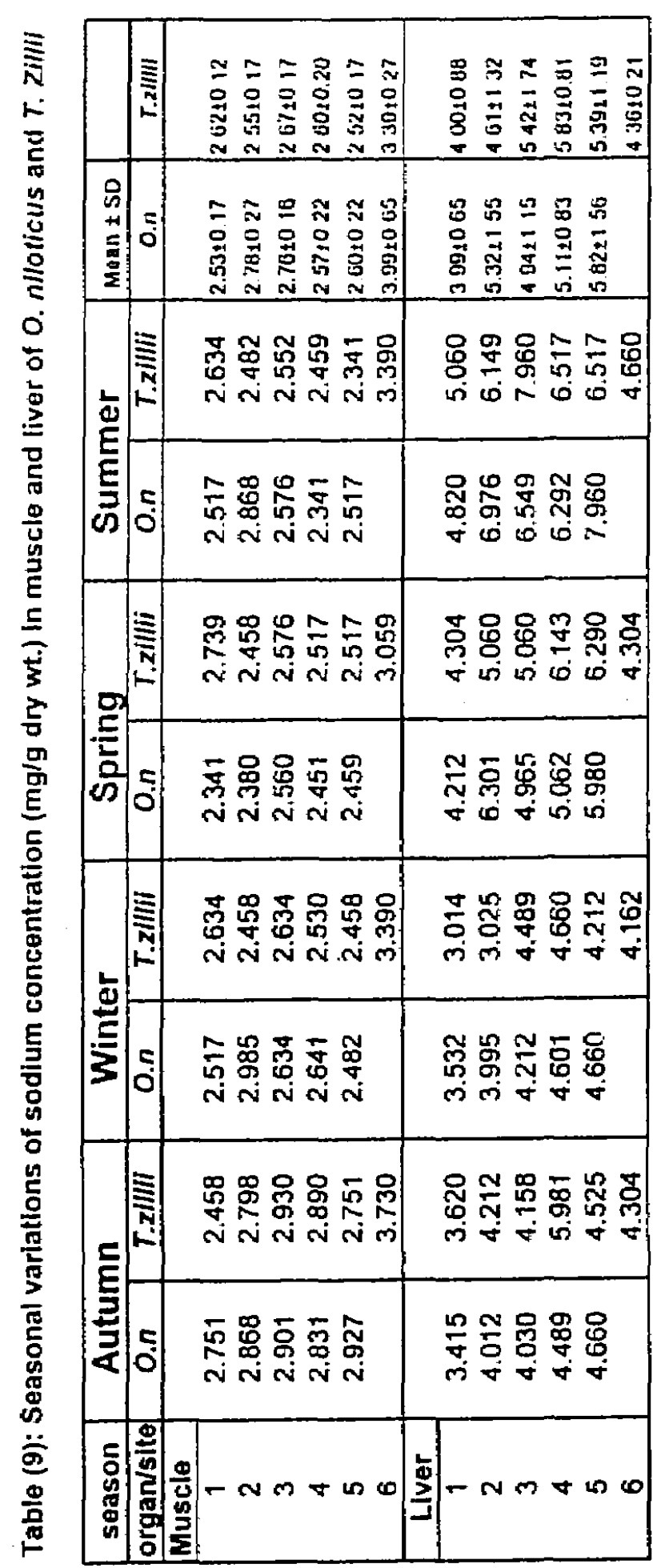

\begin{tabular}{|c|c|c|c|}
\hline (a) & 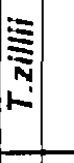 & 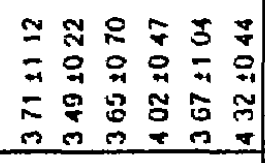 & 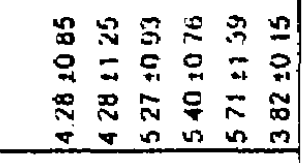 \\
\hline $\mid \begin{array}{c}1 \\
\frac{5}{5} \\
0 \\
\Sigma\end{array}$ & |. & 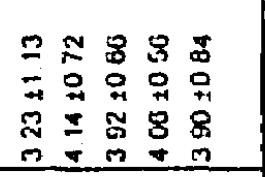 & 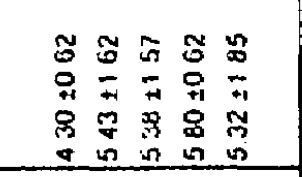 \\
\hline \multirow{2}{*}{ 这 } & 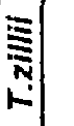 & 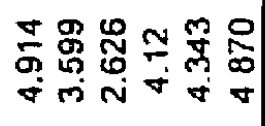 & 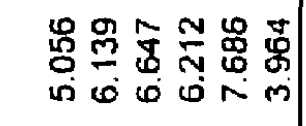 \\
\hline & & 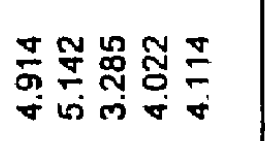 & 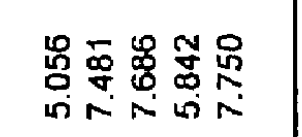 \\
\hline \multirow{2}{*}{ 음 } & 率 & 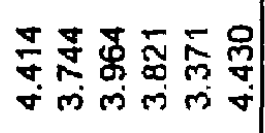 & 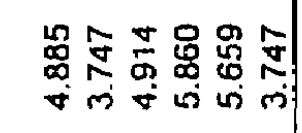 \\
\hline & & 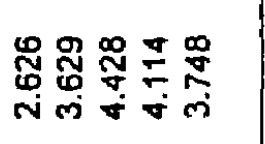 & 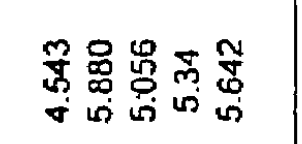 \\
\hline \multirow{2}{*}{ 产 } & 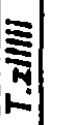 & 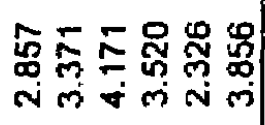 & 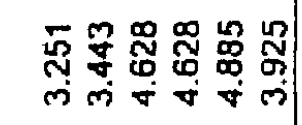 \\
\hline & ç & 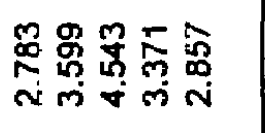 & 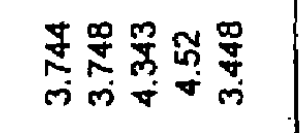 \\
\hline \multirow{2}{*}{ 点 } & - & 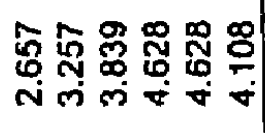 & 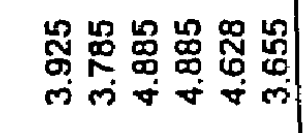 \\
\hline & 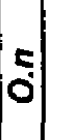 & 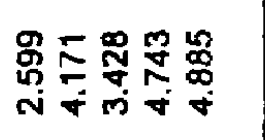 & 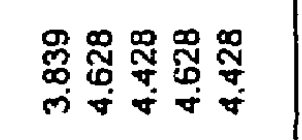 \\
\hline 量 & 噌 & $-n$ & Dٕj \\
\hline
\end{tabular}




\begin{tabular}{|c|c|c|c|}
\hline$\sigma o r \neq \omega N-\mid$ & pus & 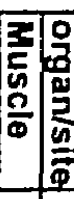 & 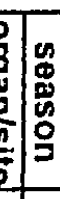 \\
\hline 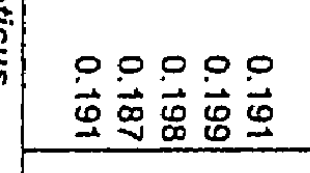 & 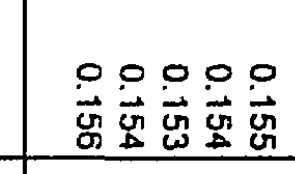 & $\begin{array}{l}0 \\
\vdots\end{array}$ & $\sum_{-1}^{2}$ \\
\hline 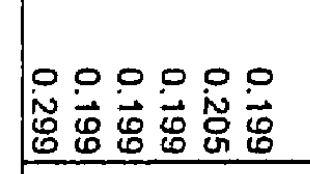 & 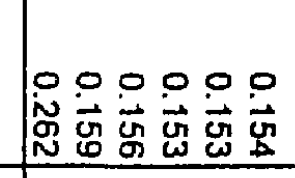 & & \\
\hline 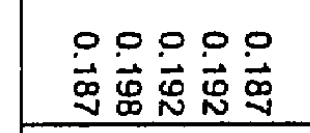 & 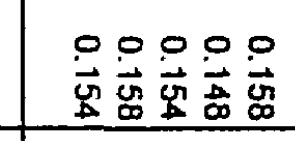 & is & $\sum$ \\
\hline 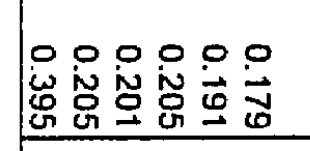 & 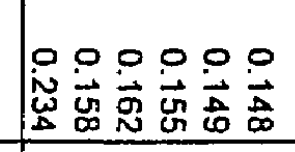 & N & \\
\hline 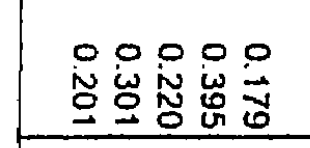 & 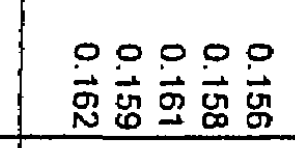 & 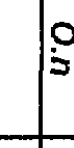 & $\frac{6}{5}$ \\
\hline 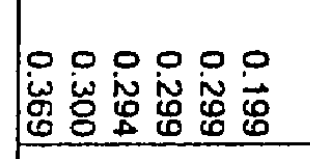 & 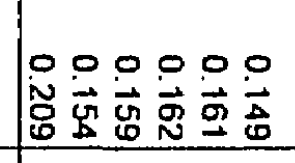 & iv & \\
\hline 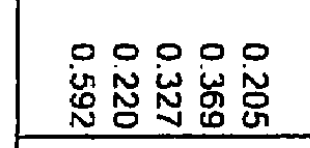 & 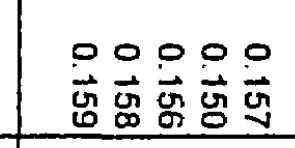 & is & 电 \\
\hline 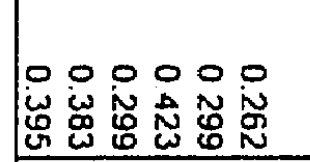 & 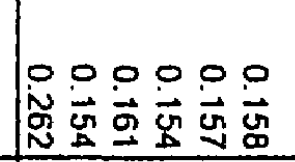 & in & \\
\hline 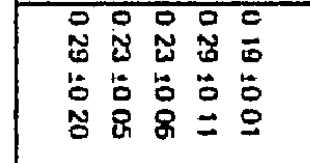 & $\begin{array}{l}00 \\
0 \\
0\end{array}$ & 0 & $\mid \begin{array}{l}3 \\
0 \\
2\end{array}$ \\
\hline 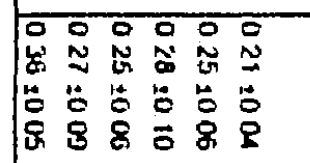 & $\mid \begin{array}{llllll}0 & 0 & 0 & 0 & 0 & 0 \\
0 & \overrightarrow{0} & 0 & 0 & 0 & 0 \\
0 & 0 & 0 \\
0 & 1 & 0 & 0 & 0 & 0 \\
0 & 8 & 8 & 8 & 0 & 8\end{array}$ & 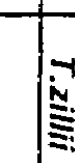 & 4 \\
\hline
\end{tabular}

\begin{tabular}{|c|c|c|c|}
\hline$\sigma o r \infty \omega N-$ & $\sigma r=\omega n-$ & 道 & 煦 \\
\hline 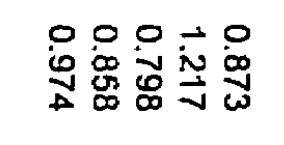 & 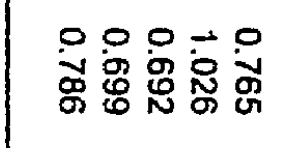 & 10 & E \\
\hline 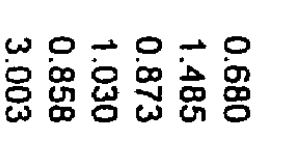 & $\mid$\begin{tabular}{l}
$N O D$ \\
\hdashline \\
\hdashline
\end{tabular} & -4 & \\
\hline 怘至芯岕密思 & 只品官宫芯 & io & $\sum$ \\
\hline 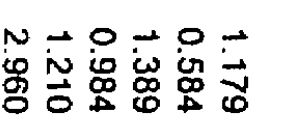 & 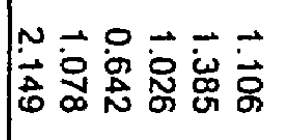 & it & \\
\hline 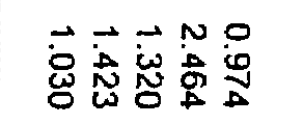 & 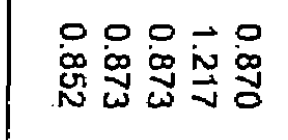 & 9 & $\frac{\infty}{7}$ \\
\hline 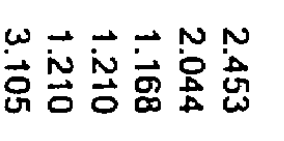 & 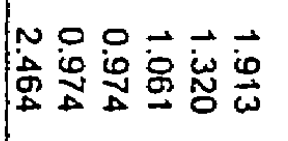 & in & \\
\hline 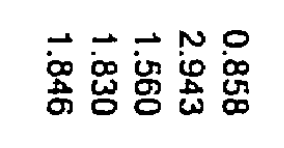 & 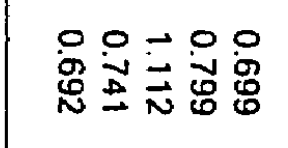 & 9 & $\stackrel{\infty}{E}$ \\
\hline 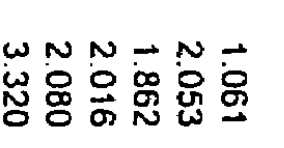 & 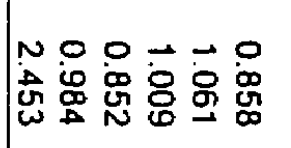 & $\stackrel{-1}{\stackrel{-1}{*}}$ & $\stackrel{\mathbb{2}}{7}$ \\
\hline 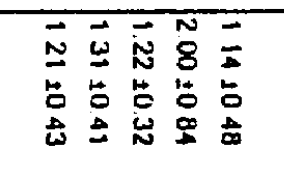 & 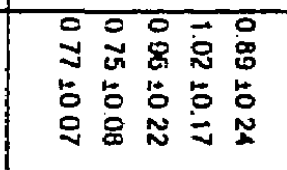 & 9 & $\begin{array}{l}3 \\
5 \\
0 \\
0 \\
0\end{array}$ \\
\hline 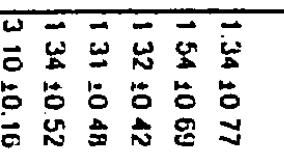 & 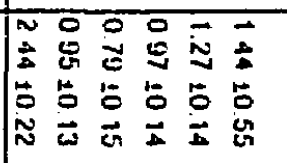 & + & 0 \\
\hline
\end{tabular}



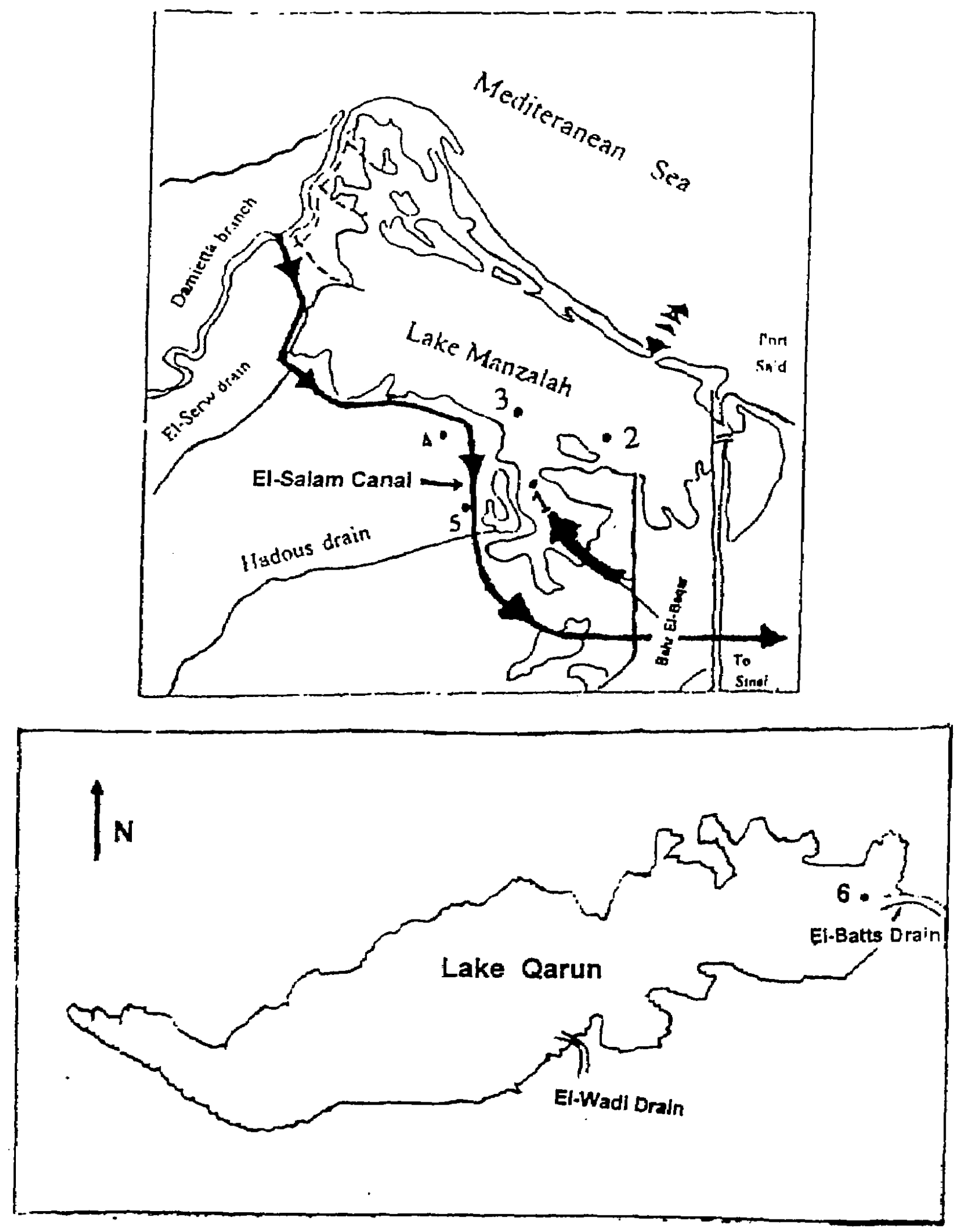

Fig. (1): Fish sampling sites in Lake Manzalah, El-Salam Canal and Lake Qarun. 